\title{
OBITUARY
}

\section{PROFESSOR KERNIAL SINGH SANDHU}

It was with shock as well as sadness that I heard the news of the sudden death, by heart attack, of Kernial Singh Sandhu on 2 December 1992. Although he had been troubled by chest pains some months ago, he always had seemed large as life and was full of enthusiasm especially over the many faceted work of the Institute of Southeast Asian Studies, of which he was the fourth and longest-serving Director since 1972.

The ISEAS as it stands today, with its pre-eminent position as a research centre for Southeast Asian affairs, is to a large extent the product of his academic entrepreneurship and diplomacy. Kernial's links with this Journal go back to his contributions to its predecessor, The Journal of Southeast Asian History, for he was a historical geographer by training, and continued with his valued role as a member of our Editorial Advisory Committee since September 1972.

He is survived by his wife, to whom we extend our deepest sympathies; and he has been succeeded as Director of ISEAS by Professor Chan Heng Chee, another member of our Editorial Advisory Committee, to whom we express our warmest congratulations and best wishes for her Directorship.

We are pleased to publish the following tribute to Kernial by his former teacher and long-time academic collaborator, Professor Paul Wheatley, a long-time Corresponding Member of our Editorial Board. We express our appreciation to ISEAS for permission to publish this tribute, which will also feature in one of its forthcoming publications.

Ernest C.T. Chew

Chairman of the Editorial Board 